\title{
RBI SHOULD LOOK BEYOND INFLATION TARGETING AND ADOPT CREDITTARGETING AS WELL
}

\author{
ANSHUL NEGI \\ Master's student, Central University of Rajasthan \\ DOI: 10.46609/IJSSER.2021.v06i04.005 URL: https://doi.org/10.46609/IJSSER.2021.v06i04.005
}

\begin{abstract}
India formally adopted a Flexible inflation targeting regime to target CPI inflation in 2016 as the primary objective of the Monetary Policy. Since then, the retail inflation has been well within 2$6 \%$ range set by the Monetary Policy Committee, but the GDP growth has declined from $8.2 \%$ in 2016-17 to $4.2 \%$ in 2019-20. At the same time, Credit growth has also seen a major decline which led to credit crunch in the Indian economy. The mandate of MPC has come to an end in March 2021. In this context, the paper tries to explain the relationship between credit growth and GDP growth in the Indian Economy and hence recommend that the Monetary Policy Committee should also adopt a Credit targeting regime along with the already existing Flexible inflation targeting framework. The paper uses Johansen (1988) Cointegration tests to illustrate the longterm relationship between the two variables.
\end{abstract}

Keywords: Credit growth, Inflation, GDP growth and Cointegration.

\section{INTRODUCTION}

“... AND WHEREAS the primary objective of the monetary policy is to maintain price stability while keeping in mind the objective of growth;

AND WHEREAS the monetary policy framework in India shall be operated by the Reserve Bank of India."

\section{- Excerpted from Preamble to the Reserve Bank of India (RBI) Act, 1934}

(amended by the Finance Act, 2016)

India has adopted a flexible inflation targeting (FIT) framework in 2016 and became the $36^{\text {th }}$ country to adopt an inflation targeting monetary policy regime. Primary objective of MPC is to keep the Consumer Price Index (CPI) at 4\% for the period from August 5, 2016 to March 2021 with the upper and lower tolerance limit of $6 \%$ and $2 \%$ respectively, while keeping in mind the objective of growth, and to meet the various challenges of an increasingly complex economy. The 


\section{International Journal of Social Science and Economic Research}

ISSN: $2455-8834$

Volume:06, Issue:04 "April 2021"

MPC would be entrusted with the task of fixing the benchmark policy rate (repo rate) required to contain inflation within the specified target level. The rationale behind adopting such a policy was the persistently high inflation especially after the global financial crisis in 2008.

"Food inflation is the worst kind of tax, affecting the poor much more as they spend most of their income on food. The government has to take a long-term view of the problem and insurethe poor against food inflation."

- Ashok Gulati, Chairman of the Commission for Agricultural Costs and Prices, in 2011

The key advantage of a range-based target is that it allows the members of the committee to letgo off the target set at $4 \%$ in the short run to trade off between inflation and growth but enablesit to pursue the inflation target over the course of business cycle which is clearly visible during the Covid -19 pandemic. After the adoption of FIT in June 2016, the government banned currency notes of INR 100 and INR 500 on November 08, 2016. Therefore, together these high value currency notes which accounts for more than $86 \%$ of the value of the total notes in circulation in 2016. The Demonetization disrupted the banking and growth in the economy. Banks were awash with liquidity and it was expected that credit growth will rise but surprisingly nothing significant happen because of the ongoing NPA issue in the banking sectors and poor domestic demand for loans in the retail sector. None of the interest rates showed any sharp movement off their long run trends around the demonetization date. This was unexpected given that the total bank credit rose by almost rupee 6 trillion. The decline of the credit growth in the economy was further accentuated by the failure of Infrastructure leasing \& Finance Leasing ltd in 2018 which led to the crisis in the Non-Banking Financial Sector (NBFC) sector. This brought India's $\$ 370$ billion shadowbanking sector to its knees and brought a slowdown in the Indian Economy.

Thus, the study attempts to historically analyze the effect of credit growth on India's GDP and recommends for the adoption of Credit Targeting framework along with the already existing Flexible Inflation targeting framework for the next five years. The rest of the paper is as follows. Following the Introduction, Section II gives a brief review of existing literature on the Inflation targeting framework and the relationship between GDP and Credit growth. Section III gives a brief about the history of Monetary Policy Framework in India and review of the current FIT framework. Section IV discusses about the proposed Credit targeting framework in this paper, Section V states the data and methodology adopted to carry out the study, Section VI discusses the relationship between Credit growth and GDP using Cointegration test. Section VII mentions recommendations and finally, Section VIII concludes withpolicy implications. 


\section{International Journal of Social Science and Economic Research}

ISSN: $2455-8834$

Volume:06, Issue:04 "April 2021"

\section{REVIEW OF LITERATURE}

The Bank credit is an important instrument that stimulates private investment and thus pushes growth in an economy. The relationship between bank credit and economic growth has been a subject of discussion for many decades all over the world especially in the under developing countries. In the $19^{\text {th }}$ century, the common notion among the enterprises was that the banks donot play a leading role in growth of an economy. This belief was challenged by Schumpeter (1911)in his innovation theory where he stated that bank have a pivotal role in the economic growth. He mentions that various economic players like Individuals, Enterprises and government takes credit from banks for consumption and investment purposes which have positive impact on the growth. Schumpeter (1934), emphasis the importance of financial institutions in the transmission of money which are essential for innovation and economic growth. Schumpeter (1970) mentions about the role of bank as a "social accountant".

Arguments in favor of the reverse causal direction have been put forth by Robinson (1952), who asserts that "where enterprise leads finance follows". According to this view, the financial system develops in response to the demand generated by a growing real economy. Tobin (1965) found out that after world war II, development was driven majorly by government intervention to promote accumulation of physical capital. This limited the reach of financial markets and limited their contribution to economic growth.

Patrick (1966) have found out two causal relationship between growth and financial system. The Demand following view asserts that as the real economy grows, demand for financial grows. On the contrary, Supply side view asserts that financial services are created in advance. Patrick mentions that, initially supply-side view is important whereas after a sustained increase in macroeconomic growth, the demand following becomes more important.

McKinnon (1973) in his study stressed that the in the developed countries, a robust financial system and capital accumulation is more important than the idle money-physical capital substitution. Shaw (1973) also emphasized on the importance of financial system for the growth of the economy. Both Shaw and McKinnon have highlighted the financial repression and decline in the growth trajectory in the developing world.

Jung (1986) found out that less developing countries (LDCs) have a supply side causality pattern whereas Developed countries (DCs) have the reverse causal direction. He used Granger causality tests to study causal relationship between financial development and economic growth for 56 countries.

Minsky (1992) stated that the role of financial intermediaries was to promote capital 


\section{International Journal of Social Science and Economic Research}

ISSN: $2455-8834$

Volume:06, Issue:04 "April 2021"

development in the economy. He also mentions that in times of high credit growth, quality can be compromised and thus it leads to a crisis thereafter. He termed it as "Minsky Point" or "Minsky Moment" which is the initial phase of a crisis in which it can lead to a credit crunch in the economy and hamper growth.

Demetriades and Hussein (1996) studied the importance of financial system for economic growth and found out little evidence of finance being the leading sector for economic development. King and Levine (1993), Gregorio and Guidotti (1995), Das and Maiti (1998), Blackburn and Hung (1998), Levine et al. (2000), Calderon and Liu (2002) also concluded the bidirectional causality between credit development and economic growth.

Bell and Rousseau (2001) studied the role of financial system in the economic growth after the independence of India. He used Vector Autoregression (VAR) and Vector Error Correction Models(VECM) and found out that the growth of financial system is effective in the increasing the aggregate investment and output in the country and promoted industrialization in the Indian economy.

Rajan and Zingales (2001), have stressed about the importance of finance for the developmentof necessary markets and institutions. They mention that opportunity arise in an economy that require financing.

Das and Khasnobis (2007) studied the mechanism from Financial intermediation to economic growth through the perpetuation of short term and long-term credit. They have found causal relationship between the two variables. Pradhan et al (2014) have studied the nexus between trade and Indian economy. He used ARDL approach to cointegration and granger causality to conclude that both the variables are cointegrated. Sehrawat and Giri (2015) has studied the impact of financial development on growth of 28 Indian states from 1993 to 2012 by using cointegration and causality tests and conclude that a bi-directional relationship exists between per capita credit and deposits.

Chen and Wu (2014) analyzed the determinants of bank credit growth in the emerging market economies during pre-crisis, crisis and post crisis period. They found out that the accommodative monetary policy supports credit growth and economic growth.

Singh, Pemmaraju and Das (2016) studied the relationship between the credit and growth in Indiain the last few decades. They have used Cointegration and Granger Causality tests to study the relationship and the empirical findings suggests that a long term cointegration relationship exists in the overall GDP and credit data during the initial period of Indian economic growth. However, the long-term relationship breaks down post 1992. 


\section{International Journal of Social Science and Economic Research}

ISSN: $2455-8834$

Volume:06, Issue:04 "April 2021"

Raj, Rath, Mitra and John (2020) evaluates the impact of asset quality of scheduled commercial banks in India on the credit channel of Monetary policy. The study finds that a robust credit channel of Monetary transmission exists in India. However, the efficacy is impaired by poor asset quality but reinforced by better capital position of banks. The study also find out that to increase the credit growth in the country, emphasis should be given to strengthen capital positions of the banks and better asset management. The study identifies the potential determinants of credit growth in India and carried out estimation by using dynamic panel data regression technique, following Arellano-Bover (1995) and Blundell-Bond (1998) in generalized method of moments (GMM) framework.

\section{History of Monetary Policy Framework in India}

The Reserve Bank was set up in 1934 under the Reserve Bank of India Act 1934 to regulate the issue of bank notes and keeping of reserves with a view to securing monetary stability in India and to operate the currency and credit system of the country to its advantage. Later, the Reserve Bank of India was nationalized in 1949. The Central bank has performed its traditional functions along the various changes it has undergone from time to time given the economic scenario in the country. The current governor of Reserve Bank of India, Mr. Shaktikanta Das, have described the evolution of monetary policy as the "Seven Ages of Monetary Policy" in India.

\section{Evolution of Monetary Policy}

1935 to 1949: The Reserve Bank of India came into existence during the British India period in the backdrop of the Great Depression. It provided the edifice for the evolution of monetary policy framework. The focus was to maintain the sterling parity by controlling liquidity through the open market operations (OMO) with other monetary policy tools like Bank Rate and Cash Reserve Ratio (CRR). Thus, exchange rate was given priority in this time period. At that time, India economy was very underdeveloped and of agrarian nature, thus inflation was a major concern because of frequent supply side shocks. Hence, alongside the various steps taken by the then government, the Reserve Bank also used selective credit control and moral suasion to restrain banks from extending credit for speculative purposes.

1949 to 1969: India became a republic on $26^{\text {th }}$ January 1950 which was a turning point in the Indian economic history. Indian policy makers adopted a model of planned based economy and the objective was to ensure a socialistic pattern of society through economic growth with a focus on self-reliance. For this purpose, Five-year plan was formulated, and the idea was intended to be achieved by building up of indigenous capacity, encouraging small as well as large scale industries, reducing income inequalities and preventing concentration of economic period. This phase was characterized by a strong role of the state and a shift in the conduct of the monetary 


\section{International Journal of Social Science and Economic Research}

ISSN: $2455-8834$

Volume:06, Issue:04 "April 2021"

policy in India.

The role of Monetary policy was to support the requirements of five-year plans. Thus, the focus was to provide credit to productive sectors. The policy instruments used to provide ample liquidity in the system was the Bank rate, reserve requirements (CRR, SLR) and open market operations.

1969 to 1985: Nationalization of major banks in 1969 led to another phase of the evolution of monetary policy. Credit growth was the major objective behind the nationalization of banks to ensure sufficient supply of credit in the economy. As, credit growth expanded in the economy, RBI faced another problem to maintain a balance between the economic growth and rising inflation because of increase in money supply from credit expansion. Besides, War between India \& Pakistan in 1971, Oil embargo by OPEC countries in 193 and Iran-Iraq war which led increase in the prices of crude oil in 1979, a severe drought in the 1973 and the collapse of Bretton Woods system in 1973 weakened the financial position of the country and also had inflationary consequences.

The monetary policy instruments used by RBI was the Bank Rate and the Open Market Operations (OMO). However, the efficacy of Bank rate was challenges as banks were high on liquidity because of deficit financing and did not approach RBI for funds whereas OMOs had a limited role to play as the domestic bond market was still underdeveloped. Hence, the average growth was around $4 \%$ while the WPI based inflation was around $8.8 \%$ during this period.

1985 to 1998: In 1985, on the recommendations of the Chakravarty Committee, monetary targeting was adopted as a formal monetary policy framework to control high inflation and promote growth in the economy. Under this framework, inflation was controlled by limiting monetary expansion in the economy. The reserve money was allowed to be used as an operating target and broad money as an intermediate target. The expected real GDP growth and tolerable level of inflation became the basis to target money supply in the economy.

The monetary policy instrument used by RBI was the Cash Reserve Ratio (CRR) but due to continued fiscal dominance, both CRR and SLR reached their peak levels in 1990. To tackle an external balance crisis and collapse in domestic growth in 1991-92, India gone through various structural reforms and the domestic economy was opened to the global companies to achieve sustainable growth and price stability. Thus, there was a shift from Fixed exchange regime to a market determined exchange rate system in 1993. Due to all such reforms, the policy tools adopted from the recommendations of the Chakravarty Committee came under question. Indian Economy seen a shift towards market-based financing for both the government and the private sector. During this time, the average domestic growth and WPI based inflation was $5.6 \%$ and 


\section{International Journal of Social Science and Economic Research}

ISSN: $2455-8834$

Volume:06, Issue:04 "April 2021"

\section{$8.1 \%$ respectively.}

1998-2015: After the reforms of 1991-92, the Reserve Bank of India abolished the monetary targeting framework and adopted multiple indicators approach in April 1998. Under this system, various forward-looking indicators such as credit, inflation, output, trade, capital flows, exchange rate, returns in different markets and fiscal performance constituted the basis of information tobe used for monetary policy formulation. The FRBM Act, 2003 also provided flexibility to monetary policy.

During this period, the short-term interest rates became the instruments to signal monetary policy stance of the RBI. Thus, in order to stabilize the short-term interest rates, RBI focused on the integration of money market with other market segments. The major monetary policy instruments used by RBI in this period were the Open Market Operations (OMO), standing facilities and changes in the reserve requirements. Quantum of marginal liquidity was affected by these instruments whereas instruments such Bank rate, reverse repo rate and repo rate affect the price of liquidity. The Multiple indicator approach performed quite well from 1998-99 to 200809. During this period, the average growth rate and WPI based inflation was $6.4 \%$ and $5.4 \%$ respectively.

2013-16: The Multiple indicator approach came into question after the Global Financial Crisis in 2008 as the persistently high inflation and weakening growth began to co-exist. The approach was also criticized because a large set of indicators do not provide a clearly defined nominal anchor for monetary policy. In 2014, an expert committee was set up by the RBI to revise and strengthen the monetary policy framework in India. The committee reviewed the already existing Multiple indicators approach and recommended that the inflation should be the nominal anchorfor the monetary policy in India.

2016 onwards: A Monetary Policy Framework Agreement (MFPA) was signed between Government of India and the Reserve Bank of India in 2015 and Flexible inflation targeting (FIT) was formally adopted. The primary objective was to maintain price stability while keeping in mindthe objective of growth. A target of $4 \%$ was set for the Consumer Price Inflation (CPI) with a tolerance band of +/- 2 percent, while simultaneously focusing on growth when inflation is under control. The mandate of MPC comes to an end in March 2021.

\section{Overview of Flexible inflation targeting regime (August, 2016 to March, 2021)}

After the constitution of MPC, the first period from October 2016 to March 2020, the average headline inflation was 3.9 percent which was well within the target set by the FIT framework. Apart from the aligning inflation from the target, the success of FIT lies in providing certainty to 
people, corporates, investors about the course of future inflation by minimizing its fluctuations. This is the crux of Price stability. Both the inflation forecasts (Figure 1) of financial professionals and the responses to inflation forecasts of households declined with the shift to IT which is an evidence that inflation has became better anchored by adopting the Flexible inflation targeting regime in 2016. Inflation volatility, which is measured by its standard deviation, declined to 1.4 in this period from 2012-16 as shown in the table 1. Skewness shows how people's expectation are also influenced by how inflation outcomes are distributed. If its above the mean, then there is a negative or left tail skew which indicates that inflation will be higher than the average and similarly, if its less than the mean or left skewed, then people expect lower than the average inflation. During the period of FIT and first MPC, skewness was 0.9 which indicates that inflation was lower than the average. The fourth moment about the mean i.e., Kurtosis, describes the proportion of inflation outcomes away from the average. Here, during this period of FIT, it was 0.9 implying that there are only very few instances of large deviations from the mean.

TABLE 1: Headline Inflation - Key Summary Statistics

\begin{tabular}{|l|l|l|l|l|l|l|l|l|l|l|}
\hline & $2012-13$ & $2013-14$ & $2014-15$ & $2015-16$ & $\begin{array}{l}\text { AVG } \\
\text { (Apr 12 } \\
\text {-Sep 16) }\end{array}$ & 2016-17 & 2017-18 & 2018-19 & 2019-20 & $\begin{array}{l}\text { AVG } \\
\text { (Oct 16- } \\
\text { Mar 20) }\end{array}$ \\
\hline MEAN & 10.0 & 9.4 & 5.8 & 4.9 & 7.3 & 4.5 & 3.6 & 3.4 & 4.8 & 3.9 \\
\hline ST. DEVIATION & 0.5 & 1.3 & 1.5 & 0.7 & 2.4 & 1.0 & 1.2 & 1.1 & 1.8 & 1.4 \\
\hline SKEWNESS & 0.2 & -0.2 & -0.1 & -0.9 & 0.1 & 0.2 & -0.2 & 0.1 & 0.5 & 0.9 \\
\hline KURTOSIS & -0.2 & -0.5 & -1.0 & -0.1 & -1.5 & -1.6 & -1.0 & -1.5 & -1.4 & 0.9 \\
\hline MEDIAN & 10.1 & 9.5 & 5.5 & 5.0 & 7.1 & 4.3 & 3.4 & 3.5 & 4.3 & 3.6 \\
\hline MAXIMUM & 10.9 & 11.5 & 7.9 & 5.7 & 11.5 & 6.1 & 5.2 & 4.9 & 7.6 & 7.6 \\
\hline MINIMUM & 9.3 & 7.3 & 3.3 & 3.7 & 3.3 & 3.2 & 1.5 & 2.0 & 3.0 & 1.5 \\
\hline
\end{tabular}

Note: Skewness and Kurtosis are unit-free

Source: RBI Report on Currency and Finance 2021 
International Journal of Social Science and Economic Research

ISSN: 2455-8834

Volume:06, Issue:04 "April 2021"

Figure 1: CPI \& GDP Growth after FIT

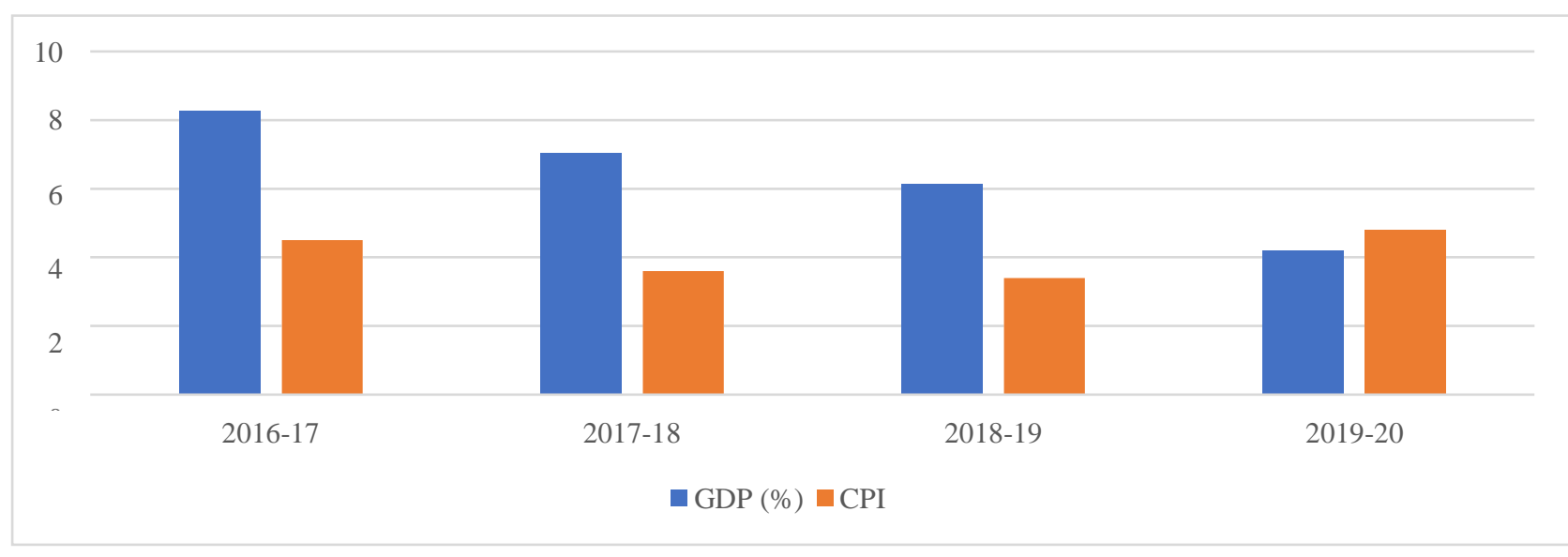

Source: Handbook of Statistics on Indian Economy (Various years)

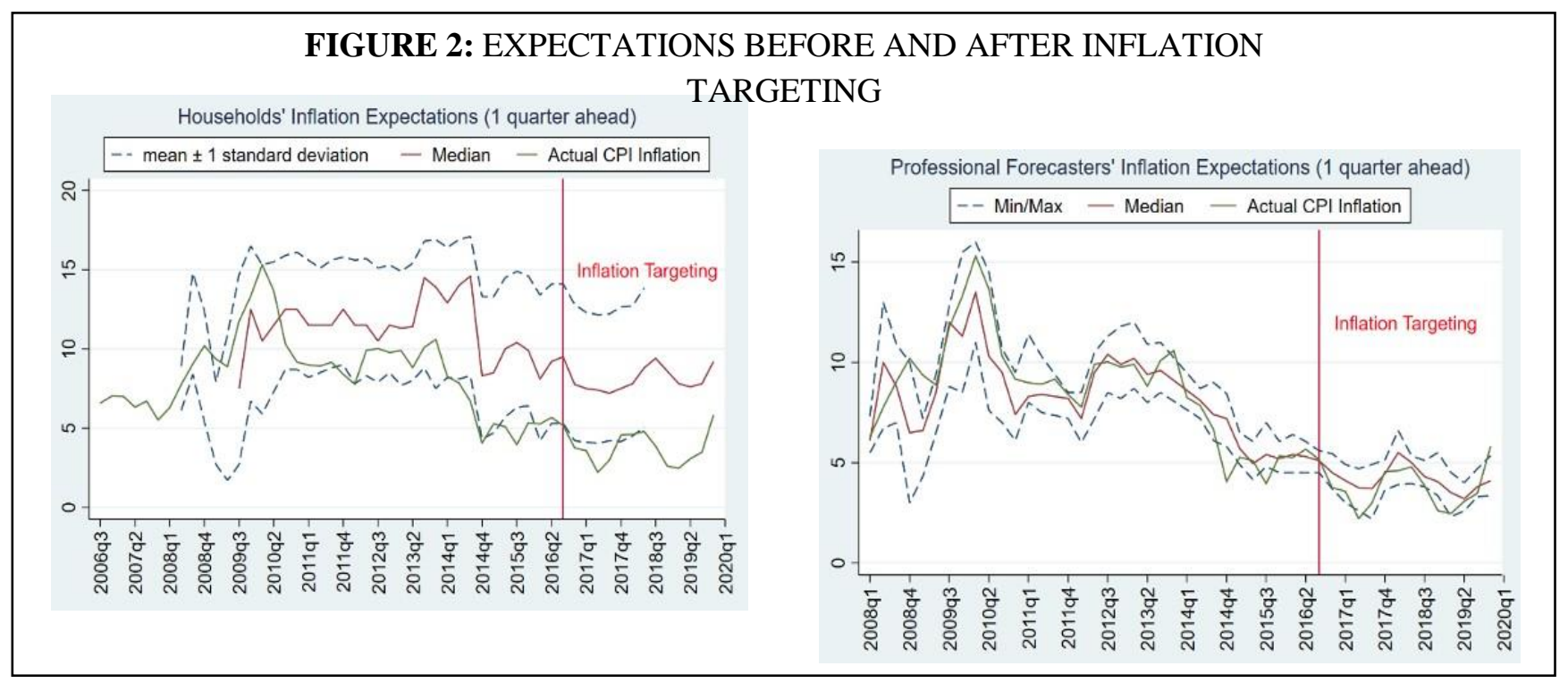

Table 2: Key Macroeconomic Indicators under FIT

\begin{tabular}{|l|l|l|l|l|l|}
\hline & CPI Inflation & $\begin{array}{l}\text { Real } \\
\text { GDP } \\
\text { Growth }\end{array}$ & $\begin{array}{l}\text { Interest } \\
\text { Rate } \\
\text { (WACR) }\end{array}$ & $\begin{array}{l}\text { App (+)/Dep (- } \\
\text { )of Exchange } \\
\text { Rate (REER 36) }\end{array}$ & $\begin{array}{l}\text { Combine } \\
\text { d GFD/GD } \\
\text { Pat }\end{array}$ \\
\hline PRE-FIT & \multicolumn{5}{|l}{} \\
\hline $\mathbf{2 0 1 2 - 1 3}$ & 10.0 & 5.5 & 8.1 & -4.3 & 6.9 \\
\hline
\end{tabular}


International Journal of Social Science and Economic Research

ISSN: 2455-8834

Volume:06, Issue:04 "April 2021"

\begin{tabular}{|l|l|l|l|l|l|}
\hline $\mathbf{2 0 1 3 - 1 4}$ & 9.4 & 6.4 & 8.3 & -2.2 & 6.7 \\
\hline $\mathbf{2 0 1 4 - 1 5}$ & 5.8 & 7.4 & 8.0 & 5.5 & 6.7 \\
\hline $\mathbf{2 0 1 5 - 1 6}$ & 4.9 & 8.0 & 7.0 & 2.9 & 6.9 \\
\hline Average & $\mathbf{7 . 5}$ & $\mathbf{6 . 8}$ & $\mathbf{7 . 8}$ & $\mathbf{0 . 5}$ & $\mathbf{6 . 8}$ \\
\hline FIT & \multicolumn{5}{l|}{} \\
\hline $\mathbf{2 0 1 6 - 1 7}$ & 4.5 & 8.3 & 6.2 & 2.2 & 6.9 \\
\hline $\mathbf{2 0 1 7 - 1 8}$ & 3.6 & 6.8 & 5.9 & 4.5 & 5.8 \\
\hline $\mathbf{2 0 1 8 - 1 9}$ & 3.4 & 6.5 & 6.3 & -4.8 & 5.8 \\
\hline $\mathbf{2 0 1 9 - 2 0}$ & 4.8 & 4.0 & 5.4 & 2.4 & 6.9 \\
\hline Average & $\mathbf{4 . 1}$ & $\mathbf{6 . 4}$ & $\mathbf{6 . 0}$ & $\mathbf{1 . 1}$ & $\mathbf{6 . 4}$ \\
\hline
\end{tabular}

Source: RBI Report on Currency and Finance, 2021

The Flexible Inflation Targeting framework has been quite successful in stabilizing the CPI based inflation in the target range of 2-6 percent. Until the pre COVID period, the inflation has exceeded the upper tolerance level on only one occasion in the fourth quarter of 2019-20. It was due to supply side factors, mainly because of unseasonal rain and late monsoon. Overall, Flexible inflation targeting framework has achieved its objective.

\section{Covid and Credibility}

In the final year of the Flexible inflation targeting regime, the world economy went into a deep recession. The MPC called for an unscheduled meeting in the last week of March 2020 and announced the biggest rate cuts in its lifetime - 115 basis points and maintained its accommodative stance to cater the needs of the economy as and when required. Later, the repo rate was brought down to 4 percent while the reverse repo rate was 3.35 percent until March 2021. The system was filled with excessive liquidity which was required to meet the demands of the economy in the wake of the crisis. This led to increase in the inflation which was over the upper tolerance band of the RBI until it came back within control in December 2020 after the fall in prices of food commodities. The flexibility in the FIT framework has given the power to RBI totake extraordinary steps in response to covid 19.

Table 3: CPI inflation after Covid 19 pandemic

\begin{tabular}{|c|c|}
\hline MONTH & $\frac{\text { CPI (C) Based }}{\underline{\underline{\text { Inflation }}}}$ \\
\hline APRIL 20 & 7.22 \\
\hline MAY 20 & 6.27 \\
\hline \hline
\end{tabular}


International Journal of Social Science and Economic Research

ISSN: $2455-8834$

Volume:06, Issue:04 "April 2021"

\begin{tabular}{|c|c|}
\hline JUNE 20 & 6.23 \\
\hline JULY 20 & 6.73 \\
\hline AUGUST 20 & 6.69 \\
\hline SEPTEMBER & 7.27 \\
$\mathbf{2 0}$ & 7.61 \\
\hline OCTOBER 20 & 6.93 \\
\hline NOVEMBER & 4.59 \\
$\mathbf{2 0}$ & 4.06 \\
\hline DECEMBER & 5.03 (Provisional) \\
\hline JANUARY 21 & \\
\hline FEBRUAURY & \\
\hline $\mathbf{2 1}$ & \\
\hline
\end{tabular}

Source: Database on Indian Economy

The inflation targeting framework allowed RBI to deviate, under exceptional circumstances without untoward consequences. Specifically, the better anchoring of inflation expectations has increased the scope for the RBI to respond to an exceptional shock like the Covid pandemic. The idea that inflation expectations were better anchored, give them more policy room for maneuver.

This paper suggests that the Reserve Bank of India should continue the existing Flexible Inflation targeting framework targeting a 4 percent inflation with 2 and 6 percent as the lower tolerance and upper tolerance limit respectively. The primary focus of FIT on price stability augurs well forfurther liberalization of the capital account and eventual internationalization of Indian rupee as well.

\section{CREDIT TARGETING}

The Secondary objective of the Flexible Inflation targeting framework was "keeping in mind the objective of growth". The GDP growth in India during this period was 1.1 percent lower than the pre-FIT period. The slowdown in the GDP growth was largely attributed to the situation of the credit crunch in the economy because of the stress in NBFC and Banking sector. The country has also gone through some structural reforms as well in this period. The FIT regime has seen a stable CPI inflation in the economy but other macroeconomic indicators like manufacturing, credit growth, private investment and consumption were declining which overall resulted in the slowdown in the economy. Some economists claim that the RBI has controlled the inflation but at the cost of GDP growth. Although, some of these macroeconomic variables were on decline ever since the global financial crisis, the NBFC crisis made it worse. Economy was undergoing a 


\section{International Journal of Social Science and Economic Research}

ISSN: $2455-8834$

Volume:06, Issue:04 "April 2021"

slowdown even before the advent of Covid 19 pandemic in March 2020.

Credit Targeting refers to setting up of predefined target of credit growth by the MPC to cater the demand of public and corporates in the economy which will solve the issue of credit crunch in the country and stimulate demand which will have a multiplier effect on the economy. Thus, this paper suggest that RBI should adopt Credit Targeting framework along with the existing Flexible inflation targeting framework to achieve its primary objective of price stability and secondary objective of growth as well.

\section{Background}

During the 2000s, India saw an investment boom. It was fueled by state banks giving out heavy loans for big infrastructure projects. But some companies taking advantage of these easy loans couldn't keep up with the repayments. That means the state banks were not getting paid back and therefore struggled to give out new loans. To keep the business moving, the shadow banks or the NBFC sector stepped in to cater the demand of the economy. These financial institutions, usually operates like an ordinary scheduled commercial bank but don't follow traditional banking rules, eventually made up an estimated third of all new loans nationwide. The loans played a pivotal role for the millions of small businesses and consumers who otherwise would have no access to credit. But in 2018, when a shadow banking giant Infrastructure leasing and financial services, defaulted on its debt repayments, its collapse sent shockwaves through the economy and shook up more traditional banks that supported the sector. This had a ripple effect. It became harder for people to buy expensive items like cars. That has hurt India's automotive industry which one of the country's biggest industry. It employees about 35 million people and make up about $7 \%$ of India's GDP. In 2019-20, the Industry suffered its worst sale performance in nearly 19 years, and report suggests that tens of thousands of workers have been laid off. The Agriculture and Construction sectors have also been hurting, with small and medium businesses being hit the hardest. The country's unemployment rate has also been on an upward trend since July 2017, rising several percentage points to $7.7 \%$. High unemployment means consumers will buy less, thus leading to an unfortunate cycle of slower manufacturing, production, investment and job creation.

\section{Relationship between Credit growth and GDP growth in India}

Banks are the main source of credit in the economy and they evolve in response to needs of the economy. Increase in bank credit creates demand in the economy for goods and services and thus have an impact on GDP growth as well. In this figure, it shows that most of the time credit growth and GDP growth moves in the same direction and after the global financial crisis in 2008, both credit growth and GDP growth is declining in the economy which was further fueled by 
International Journal of Social Science and Economic Research

ISSN: 2455-8834

Volume:06, Issue:04 "April 2021"

increase in NPA of scheduled commercial banks, NBFC crisis and advent of the covid pandemic in2020. Thus, credit growth and GDP growth has a positive relationship.

FIGURE 3: Time series data of Credit growth and GDP growth in India (1970-2020)

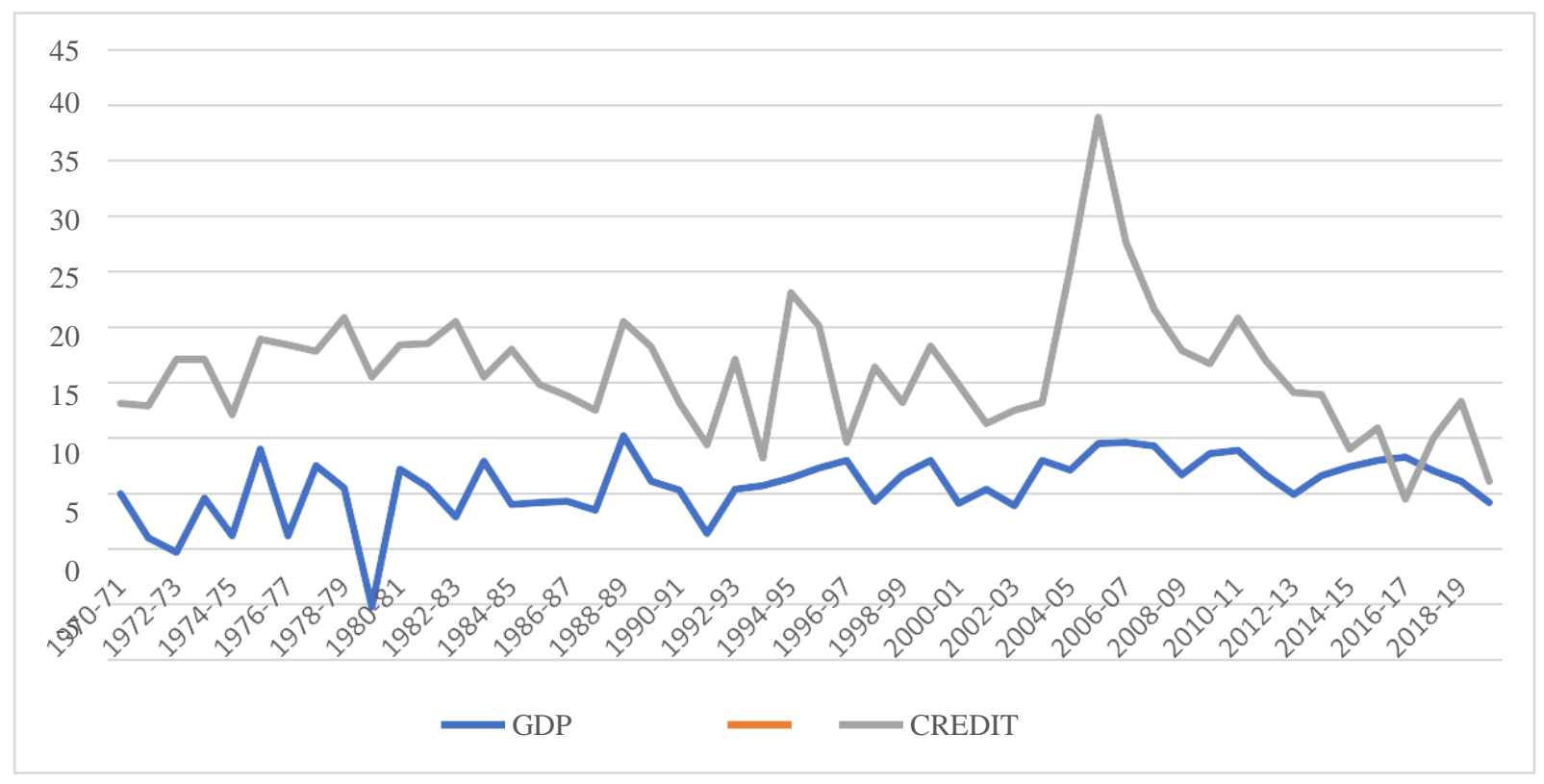

Source: Database on Indian Economy, RBI Annual reports (Various years).

\section{Shift in Bank lending pattern}

Prior to the Global Financial crisis in 2008, Indian commercial banks have started seeing a deterioration in their quality of their assets, majorly because of the of rising NPAs or the inefficiency of the corporate houses to repay their loans. This led to the gradual shift in the lending practices of the Indian banks after 2013 and has more or less changed the business models of the banks. Historically, Industrial lending in India has always been more than the retail lending. Industrial lending peaked at 46.3 percent as a proportion of total non-food credit in India in February 2013, whereas the retail lending as a proportion of non-food credit was 18.45 percentin the same time period. From then onwards, Industrial lending has been falling over the years and retail lending has been gaining momentum. Also, to be noted, in the same time private investment has been continuously falling followed by a slowdown in the Indian economy because of NBFC crisis and thus creating a situation of credit crunch in the country. 
International Journal of Social Science and Economic Research

ISSN: 2455-8834

Volume:06, Issue:04 "April 2021"

FIGURE 4: Shift in the commercial bank lending pattern

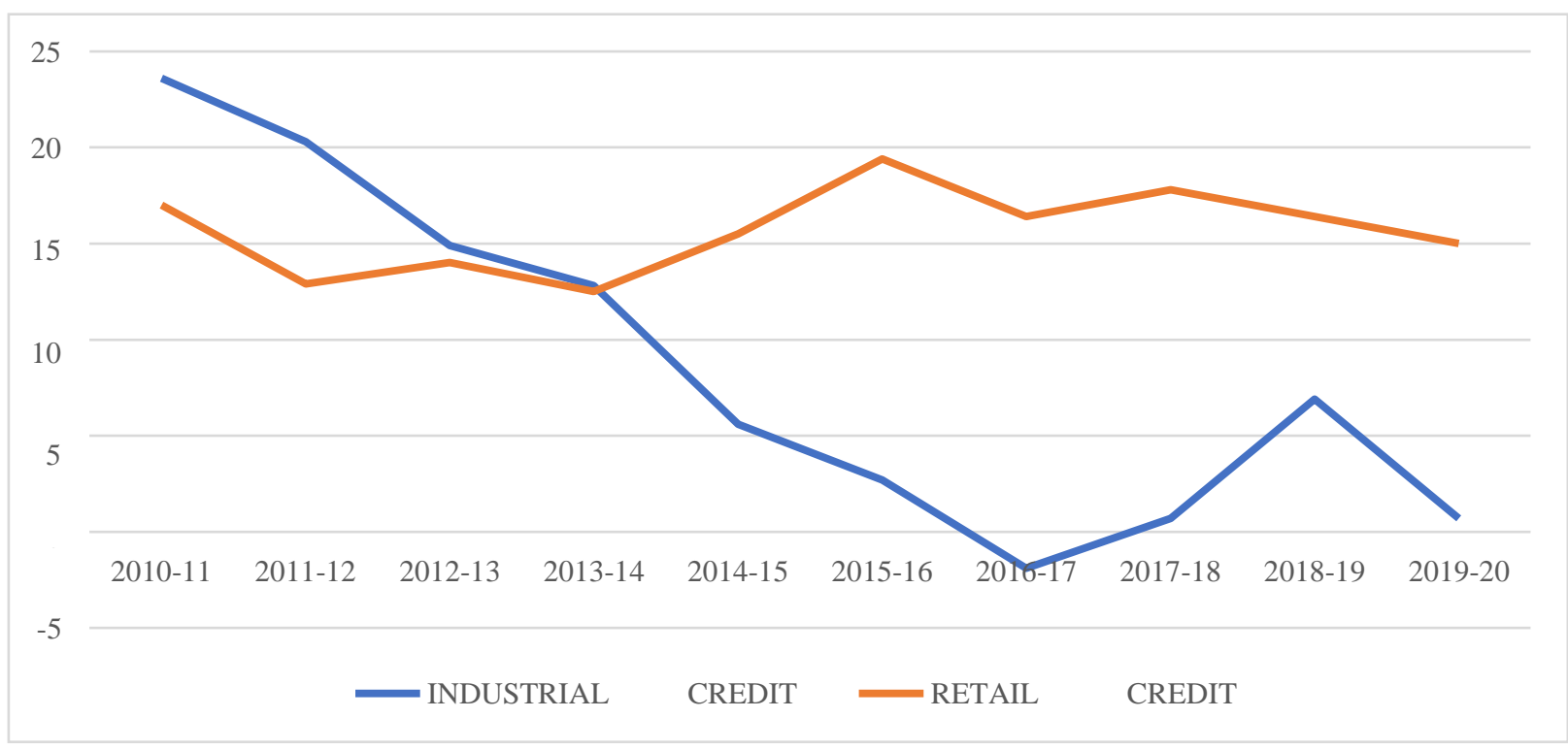

Source: Annual reports of RBI (Various years)

Over a period of five years, the commercial bank lending to the industry has gone up meagerly be 40,731 crores or just $1.5 \%$. In the same time period, the interest rate on giving out loans by banks has declined from $10.54 \%$ to $8.19 \%$. Thus, the data clearly shows that the RBI policy to cut interest rates in times of slowdown because of lack of credit in the country don't necessarily lead to higher lending. However, low interest rates accompanied by high inflation puts pressure on the deposits rate which hurts the interests of small savers and leads to negative interest rates forsavers, which again worsens the consumption demand in the economy. Hence, a credit targeting framework will make sure that the credit needs of the commercial sector will be met which will drive investment and further contribute to the GDP and employment growth in the economy.

\section{Data and Methodology}

In the study, annual data on bank credit and GDP growth spanning from FY 1970-71 to 2019-20 has been taken from NSO website and the Annual reports published by the RBI over a period of time. The current study wants to find out the relationship between the credit growth and GDP growth in the Indian economy. This has been achieved in four steps, first step is unit root test, second step uses cointegration to test long run relationship between the variables, third step is to run granger causality test and the fourth step is to estimate the effect of bank credit on GDP growth using dynamic panel data technique. The various econometric tools used in this study are as follows: 
UNIT ROOT TEST: The stationarity property of the variables has been tested by incorporating three panel unit root tests i.e., ADF -Fisher and PP -Fisher test. The test carries out the following regression for the time series:

$$
\Delta \mathrm{yt}=\alpha+\theta t+\lambda y t-1+\sum_{i=1}^{m} \theta \Delta \mathrm{yt}-1+\mathrm{e}
$$

where, $\alpha=$ Intercept

$\theta t=$ Time trend

$$
\sum_{i=1}^{m} \theta \Delta y t-1=\text { Lagged Value of the dependent variable }
$$

Here, the H0: Series is not stationary.

H1: Series is stationary.

Rejection of null hypothesis implies that the series does not have a unit root. And in case the null is not rejected, the series will be differenced and the ADF test will be conducted until the null hypothesis is rejected.

The study uses two tests to check the stationarity of the variables because if the series has anMA structure then the PP unit root test is a better alternative whereas if the series has an AR structure, then ADF test is more reliable.

Co-integration Test: To analyze the given time series data with conventional methods like ordinary least squares (OLS), an assumption has been made: the variances and mean of the series are constants that are independent of time (i.e.; processes are stationary). Non-stationary time series don't meet this assumption, so the results from any hypothesis test will be biased or misleading. These series have to be analyzed with different methods. One of these methods is called cointegration. Cointegration tests analyze non-stationary time series processes that have variances and means that vary over time period. In other words, the method allows to estimate the long run parameters or equilibriums in systems with unit root variables.

In this study, the author is using Johansen cointegration test to find out the long run relationship between the variables. The benefit of using Johansen Cointegration is that it does not solve a single equation by single equation itself like in Engle - Granger test. Rather, it solves it by using the endogeneity in the equation and make several equations out of it and checks cointegration in 
International Journal of Social Science and Economic Research

ISSN: $2455-8834$

Volume:06, Issue:04 "April 2021"

every equation. Thus, it gives cointegration in different equations.

Johansen test uses two types of statistics: Trace statistics and Max Eigen values statistics.

Here, the H0: No Cointegration.

H1: Existence of Cointegration.

If the Trace value/Max Eigen value is greater than the critical value, then reject $\mathrm{H} 0$ which shows there is cointegration. However, If Trace statistics and Max Eigen statistics shows different results, then in that case the results obtained by Trace value statistics is more appropriate.

\section{RESULT AND DISCUSSION}

\section{UNIT ROOT TEST:}

\begin{tabular}{|c|l|l|l|l|}
\hline $\begin{array}{c}\text { VARIABL } \\
\text { ES }\end{array}$ & \multicolumn{2}{|c|}{ ADF- Fisher TEST } & \multicolumn{2}{c|}{ PP } \\
\hline & Level & $1^{\text {st }}$ diff & Level & $1^{\text {st }}$ diff \\
\hline LCG & -0.55 & -10.37 & -0.67 & -12.85 \\
& $(0.4713)$ & $(0.00)$ & $(0.4195)$ & $(0.00)$ \\
\hline LGG & -0.25 & -15.68 & -1.64 & -23.82 \\
& $(0.5890)$ & $(0.00)$ & $(0.0933)$ & $(0.00)$ \\
\hline
\end{tabular}

Source: Author's estimation

Here, ADF and PP test has been used to check the stationarity of the variables, namely Credit Growth and GDP growth from the year 1970-71 to 2019-20. The results shows that all the variables are non-stationarity at level whereas stationary at their first difference. Stationarity is the must condition to check the long run relationship between the variables. Thus, after first differencing, we can run the cointegration test.

\section{COINTEGRATION TEST:}




\begin{tabular}{|c|c|c|c|c|}
\hline $\begin{array}{l}\text { Hypothesized } \\
\text { No. of CE(s) }\end{array}$ & Eigenvalue & $\begin{array}{l}\text { Trace } \\
\text { Statistic }\end{array}$ & $\begin{array}{c}0.05 \\
\text { Critical Value }\end{array}$ & Prob. ${ }^{* *}$ \\
\hline None * & 0.251318 & 12.42598 & 12.32090 & 0.0480 \\
\hline At most 1 & 0.006395 & 0.269464 & 4.129906 & 0.6640 \\
\hline
\end{tabular}

Trace test indicates 1 cointegrating eqn(s) at the 0.05 level

${ }^{*}$ denotes rejection of the hypothesis at the 0.05 level

${ }^{* *}$ MacKinnon-Haug-Michelis (1999) p-values

Unrestricted Cointegration Rank Test (Maximum Eigenvalue)

\begin{tabular}{ccccc}
\hline \hline $\begin{array}{c}\text { Hypothesized } \\
\text { No. of CE }(\mathrm{s})\end{array}$ & Eigenvalue & $\begin{array}{c}\text { Max-Eigen } \\
\text { Statistic }\end{array}$ & $\begin{array}{c}0.05 \\
\text { Critical Value }\end{array}$ & Prob. $^{* \star}$ \\
\hline \hline None ${ }^{*}$ & 0.251318 & 12.15651 & 11.22480 & 0.0342 \\
At most 1 & 0.006395 & 0.269464 & 4.129906 & 0.6640 \\
\hline \hline
\end{tabular}

Max-eigenvalue test indicates 1 cointegrating eqn(s) at the 0.05 level

* denotes rejection of the hypothesis at the 0.05 level

${ }^{\star *}$ MacKinnon-Haug-Michelis (1999) p-values

Source: Author's estimation

Cointegration test is used in the study to establish the long run relationship between the Credit and GDP growth in the economy from 1970-71 to 2019-20. Since, the series is stationary at I(1). Here, after running the Johansen cointegration test on EViews, it is found that the variables exhibit a long-term relationship and thus they are cointegrated.

"On the basis of the long-term relationship between the Credit growth and the GDP growth, sluggish credit growth in the economy for the last few years, decrease in the private investmentover the years and continuous decline in the GDP growth since 2016, this paper recommends that the RBI must adopt a Credit Targeting framework for the next 5 years in which the RBI must use its policy rates to target a minimum $15 \%$ credit growth in the economy. On the otherhand, RBI should also continue with the Flexible Inflation Targeting framework."

\section{Why 15 percent?}

The low penetration of credit as a percentage of GDP in Indian economy suggests that the channels of credit have massive potential to grow. The credit growth in India declined to $6.1 \%$ in 


\section{International Journal of Social Science and Economic Research}

ISSN: $2455-8834$

Volume:06, Issue:04 "April 2021"

2019-20 from $20.8 \%$ in 2010-11. The credit-to-GDP ratio in India is around $56 \%$ when comparedto many developed economies where this ratio is in the range 150-200\%. The RBI board members suggested that the credit-to-GDP ratio in India must double to 100 percent. In order to meet thistarget and meet the demands of credit in the Indian economy and booster the growth in the private sector including the MSME sector which employs majority of labor in India, the credit growth needs to more than double to $15 \%$. The decline in credit growth post 2013 is due to theworsening of asset quality of scheduled commercial banks accentuated by the slowdown in the economy and later NBFC crisis. India needs to strengthen in capital position of banks and address their asset quality concerns. Moreover, banks should be encouraged to lend to MSME and largeindustrial houses. Also, the govt should continue with its Emergency credit line guarantee scheme (ECLGS) for the inclusive growth of the Indian economy.

\section{Recommendations (Apart from Credit Targeting)}

- Monetary Policy Committee should also have a control over the reverse repo rates as it is the total interest rate structure which determines the inflation in the economy. Moreover, in the last few months in the year 2020, the power of the MPC has become toothless because excessive liquidity in the market has made repo rate irrelevant to the overnight rates. The overnight rates were below the reverse repo rate.

- The Govt of India should issue the Market Stabilization bonds (MSS) to soak up extra liquidity from the system and thus provide a cushion to the Reserve Bank of India to bring back the inflation within the desired level of FIT framework.

- The external members of the MPC which are appointed by the Govt of India should not be dissolved simultaneously at a same time as it decreases the policy making efficiency of the committee and leads to delays. The September, 2020 MPC meeting has been postponed because the panel didn't have enough members to convene.

- In India, the members of the MPC have a silent or shut period under which MPC members are not allowed to comment on the matters related to the monetary policies. It starts seven days before the voting day and ends seven days after the policy is announced. These 7 days shut period after the MPC resolution is not at par with the global standards. It is recommended that it should be reduced to 3 days after the monetary policy announcement. 


\section{International Journal of Social Science and Economic Research}

ISSN: $2455-8834$

Volume:06, Issue:04 "April 2021"

\section{CONCLUSION}

\section{"Economics is a technique of thinking... not a body of settled conclusion" - John Maynard Keynes}

In India, the credit growth and GDP growth has declined significantly during the Flexible Inflationtargeting regime adopted by the RBI in 2016. However, the primary objective of price stability has been successfully achieved by the RBI, the secondary objective of growth has still not been achieved. Even with the easy monetary policy and accommodative stance of the RBI, the issue of credit crunch has not been resolved which led to a slowdown in the Indian Economy. In this context, this paper attempt to find out the relationship between Credit and GDP growth. The empirical findings suggests that a long-term relationship exist between the variables and thus on the basis of the findings, this paper recommends that RBI must adopt a Credit targeting framework along with the Flexible inflation targeting framework and must attempt to target a minimum 15 percent credit growth in the economy to meet the requirements of the economy and aim for higher growth in the coming years. However, this study also emphasis that Indian banks should also adopt global standards while granting loans and restrain themselves to give loans to low credit worthy borrowers. Whereas, the government must address asset quality concerns of the banks and help them strengthen their capital positions.

\section{REFERENCES}

1. Schumpeter J.A. (1911), "The theory of economic development”, New York, Oxford University Press, 1934

2. Schumpeter J.A. (1970), “The nature of money”, Vanenhoeck and Ruprecht, Gottingen

3. Robinson J. (1952), "The Generalization of the General Theory, in The Rate of Interest andOther Essays", London, Macmillan.

4. Tobin J. (1965), "Money and Economic Growth”, Econometrica, Volume 33.

5. Patrick H.T. (1966), "Financial Development and Economic Growth in Underdeveloped Countries”, Economic Development and Cultural Change, Vol. 14, No. 2.

6. McKinnon R. I. (1973), "Money and Capital in Economic Development", Washington DC, The Brookings Institution.

7. Shaw, Edward S. (1973). Financial Deepening in Economic Development, New York: OxfordUniversity Press. 
International Journal of Social Science and Economic Research

ISSN: 2455-8834

Volume:06, Issue:04 "April 2021"

8. Jung W.S. (1986), "Financial Development and Economic Growth: International Evidence", Economic Development and Cultural Change, Vol. 34, No. 2.

9. Minsky, H.P. (1986), "Stabilizing an Unstable Economy”, New Haven and London, Yale University Press.

10. Minsky, H.P. (1992), “The Financial Instability Hypothesis”, WP 4, The Jerome Levy Economics Institute of Bard College.

11. Demetriades P. O. and Hussein K.A. (1996), "Does financial development cause economic growth? Time-series evidence from 16 countries", Journal of Development Economics, Vol. 51.

12. King, R. G., \& Levine, R. (1993). Finance, entrepreneurship and growth. Journal of Monetaryeconomics.

13. De Gregorio, J., \& Guidotti, P. E. (1995). Financial development and economic growth. Worlddevelopment.

14. Das, P. K., \& Maiti, P. (1998). Bank credit, output and bank deposits in West Bengal and selected states. Economic and political Weekly.

15. Blackburn, K., \& Hung, V. T. (1998). A theory of growth, financial development and trade.Economica.

16. Levine, R., Loayza, N., \& Beck, T. (2000). Financial intermediation and growth: Causality and causes. Journal of monetary Economics.

17. Calderón, C., \& Liu, L. (2002). The direction of causality between financial development andeconomic growth. Journal of development economics.

18. Bell C. and Rousseau P. L. (2001), "Post-independence India: a case of finance-led industrialization? Journal of Development Economics, Vol. 65.

19. Rajan, R. G., \& Zingales, L. (1998). Which capitalism? Lessons from the east Asian crisis. Journalof Applied Corporate Finance.

20. Rajan, R. and Zingales, L. (2001), "The Great Reversals: The Politics of Financial Developmentin the 20th Century" NBER Working Paper No. 8178, National Bureau of Economic Research, Cambridge, MA.

21. Das, P. K. and Khasnobis, B. G. (2007), "Finance and Growth: An Empirical Assessment of theIndian Economy”, United Nations University - World Institute for Development 
International Journal of Social Science and Economic Research

ISSN: 2455-8834

Volume:06, Issue:04 "April 2021"

EconomicsResearch, Research Paper No. 2007/13.

22. Pradhan, R. P., Arvin B. M., Norman, N. R. and Nishigaki, Y. (2014), "Does banking sector development affect economic growth and inflation? A panel co-integration and causality approach", Applied Financial Economics, Vol 24: 7.

23. Sehrawat, M. and Giri A. K. (2015), "The Role of Financial Development in Economic Growth:Empirical Evidence from Indian States", International Journal of Emerging Markets, Vol. 10.

24. Chen, G., \& Wu, Y. (2014). Bank ownership and credit growth in emerging markets during andafter the 2008-09 financial crisis-A cross-regional comparison. IMF Working Paper WP/14/171, International Monetary Fund, Washington D.C.

25. Singh C (2016), “An Essay on Banking and Macroeconomics: Role of Public Sector Banks in India" IIMB WP 530.

26. "Statutory and Institutionalized framework for Monetary Policy; Central Government I consultation with RBI announces the Inflation Target of Four Percent", PIB, Govt of India, 2016.

27. "Banks to see 15\% plus credit growth in FY22-25 period: ICICI securities", Business line, March, 2021.

28. Adhikari, Anand, "Blame bad loans for credit growth woes: RBI", Business today, April, 2021.

29. Ghosh, Chandrasekhar, "Changing trends in bank credit, post demonetization", Business line, September, 2019.

30. Dave, Neha, "Credit growth well in excess of nominal GDP growth, but will it sustain?”, Moneycontrol, December, 2018.

31. Merwin, Radhika, "Demonetisation to hit bank credit growth", BusinessLine, January, 2018.

32. Lahiri, Amartya, "Deposits after demonetization rose by 6 trillion and yet bank credit fall”, March, 2020.

33. Kumar, Pai, "Expand credit to boost growth”, March, 2019.

34. "Former RBI Guv D Subbarao says Inflation targeting framework must be continued", CNBC- TV 18, March, 2021. 
35. "India need more banks to double credit-to-gdp ratio to 100 percent : RBI board member", BusinessToday, September, 2020.

36. "India needs to double credit growth to $15 \%$ to achieve $\$ 5$ trillion economy: Bankers", BusinessLine, February, 2020.

37. Dugal, Ira, “The long stinging tail of India's credit crisis”, BloombergQuint, October, 2019.

38. Eichengreen, Gupta and Choudhary, "Inflation targeting in India: an interim assessment”, VOXEU CEPR October, 2020.

39. Kumar, "NPAs: Cleaner of banks or killer of Indian economy?", The times of India, December, 2020.

40. "Viral Acharya's prescription to increase India's credit-to-gdp ratio", Economic times, July, 2020. 